IIUC STUDIES

ISSN 1813-7733

Vol.- 7, December 2010

(Published in December 2011) (p 197-220)

\title{
The Influence of the Local Varieties on the Sound Patterns of English: A Case Study of Bangladeshi Tertiary Students
}

\author{
Muhammad Azizul Hoque*
}

\begin{abstract}
This paper is an outcome of the study that was directed to investigate the influence of the local varieties on the sound patterns of English of Bangladeshi tertiary students. The study deals with the existing pronunciation style and tries to identify the problems in the light of the rural background of the students. The study is qualitative by nature illuminating qualitative data, and the methods of data collection consist of record keeping of words through direct interview, reading passages and dialogues. The results of the study are the mispronunciation of English words because of the influence of local varieties, ignorance and lack of the Standard English pronunciation system, etc. On the basis of the findings, some pedagogical implications and recommendations have been made.
\end{abstract}

\section{Introduction}

Now-a-days it is undeniable fact that English has become a language of global communication. It is used for higher education, seminars, symposium and various other purposes. From both national and international points of view, the importance of English is unquestionable. Knowledge in English, especially spoken English, has a great demand in the competitive job market. But it is a common scenario that among the four skills, spoken English is the most neglected area in Bangladesh. As a result, the level of speaking skills here is very poor. In spite of being the students of higher institutions, they feel shy to communicate and exchange views in English, and whatever is spoken is not free from the influence of their local

\footnotetext{
* Lecturer, Department of English Language and Literature, IIUC.
} 
varieties. Same word is pronounced differently according to the differences of their local backgrounds. For example, a student from Comilla pronounced 'victory'/vıktarı/ as /blkturı/ and another student from Natore pronounced as / bhıkto:ri/. This variation in pronunciation puzzles the listeners, especially the foreigners.. Though it is not mandatory to have native like fluency, it is an art to be able to speak in English as good in standard as possible. So in the present day context of the ever expanding globalization it is being realized by the researcher that the level of speaking skills of the tertiary students should be improved. And being able to avoid the influence of local varieties is a big thing for this improvement.

\section{The Status of Spoken English in Bangladesh}

As a neglected area, the status of spoken English in Bangladesh is very poor. Worse even, students' proficiency in this skill is never tested at all in any public examinations. In Bangladesh so far English language learning is concerned, listening and speaking are the two skills not tested at either SSC or HSC level or for that matter at any other level. Consequently, as a negative wash back effect, these two skills are generally excluded from the teaching objectives of English language teachers. Such teachers are mostly preoccupied with the reading, writing and grammar sections of the text books and all those features that would be relevant to passing the SSC and HSC examinations.

In this context, Amin (2006) thinks that speaking as a skill cannot be taught effectively separate from the other skills. Although almost everyone is aware of the importance of the mastery of the speaking skill in English for higher studies and good jobs, most learners do not make any effort to learn the skill. As a result there is hardly any learning in mastery of the speaking skill. In this regard, he pointed out a number of inherent problems for the Bangladeshi speakers of English:

- It is an interpersonal skill. One can listen, read and write on one's own. But for speaking there must be more than one person for interaction.

- Apart from mastery of the structures of the language, one must pay attention to acceptable/comprehensible pronunciation, stress and intonation. 
- Exposure to the language and practice in its use are essential for speaking a language. In Bangladesh both are lacking.

- In Bangladesh, the only place where students can practice speaking English is educational institutions. In most schools, colleges and universities very few students speak in English.

- A language is learned or acquired either for integrative or instrumental needs. Bangladeshi speakers of English lack both these needs. (3-4)

Sultana and Arif (2007) have pointed out some reasons of mispronunciation for the Bengali learners of English, such as:

- Learners are not conscious of the difference between the letters and sounds of a word;

- Learners do not give emphasis on the pronunciation of the sounds of a word when it is spelt;

- Learners cannot follow either syllabic or phonological divisions of words properly.

They also think that the non-native English users in Bangladesh use various local dialects with different pronunciations and intonations which influence the use of English. For example, the people of Barishal, a district and division, are often prone to pronunciation mistakes in words beginning with ' $\mathrm{B}$ ' and ' $\mathrm{V}$ ', both in English and Bangla. (137-138)

\section{Aims and Rationale}

The frequent communications with the tertiary students as a university teacher in English have enhanced the experience of the researcher of the accent of the students' English pronunciation. This has encouraged him to go ahead with studying the pronunciation of English of the tertiary students in Bangladesh. It is to be noted that the Bangladeshi students are:

- oriented to Bangla and different Bangladeshi local varieties;

- familiar with Bangladeshi English which can be termed as Banglish;

- and unfamiliar with world recognized IPA symbols and less oriented to standard worldwide recognized RP Englishes. 
So here the aim of this study is to explore-

- how Bangladeshi tertiary students perform in spoken English;

- how their Bangla and local varieties interfere in this regard;

- and how to create an awareness among the students about the standard English sound patterns.

For the purposes of this study, the questions that have haunted the researcher and made the framework of this research are:

1. What differences are usually noticed among the tertiary students coming from different local varieties?

2. What problems do they face in their spoken English for the influence of their local varieties?

3. What standard do they maintain in carrying on communication in English?

\section{Literature review}

There have been some studies on the problems and difficulties of English pronunciation for Bangladeshi speakers of English (Hai and Ball, 1961; Rahman, 1995; Banu, 2000; Muzaffar, 1999).

In a longitudinal study, Hai and Ball (1961) have made a comparative study between the sound structures of English and Bengali. They have observed the comparison and the difference in both segmental phonemes and supra-segmental features of these two languages. In their observation, they have found that in both languages there are some distinct and some common vowels, and their number in Bengali is 7 and in English 12. They are presented in the following table:

\begin{tabular}{|l|l|l|}
\hline \multicolumn{1}{|c|}{ Phonetic Symbol } & $\begin{array}{l}\text { Language in which it is } \\
\text { used }\end{array}$ & Key word \\
\hline $\mathbf{i}:$ & English & feel \\
'i' (between English i: and i ) & Bengali & fill \\
English & English and Bengali & bed \\
'a', & English and Bengali & cat \\
'ag', & Bengali & bhat (rice) \\
da: & English & part \\
'כ' & English and Bengali & hot \\
D: & English & walk \\
\hline
\end{tabular}




\begin{tabular}{|l|l|l|}
\hline '0'(like the first part of English & Bengali & g0'l (round) \\
diphthong ou) & & \\
$\mathbf{U}$ & & full \\
$\mathbf{u}$ ''(between English u:and $\mathbf{u})$ & English & chu'l (hair) \\
$\mathbf{u :}$ & Bengali & fool \\
$\mathbf{n}$ & English & but \\
$\mathbf{a}$ & English & above \\
$\mathbf{3 :}$ & English & shirt \\
& English & \\
\hline
\end{tabular}

\section{Diagram 2. The relative Positions of English and \\ Bengaii Siniple Vowel Sounds}

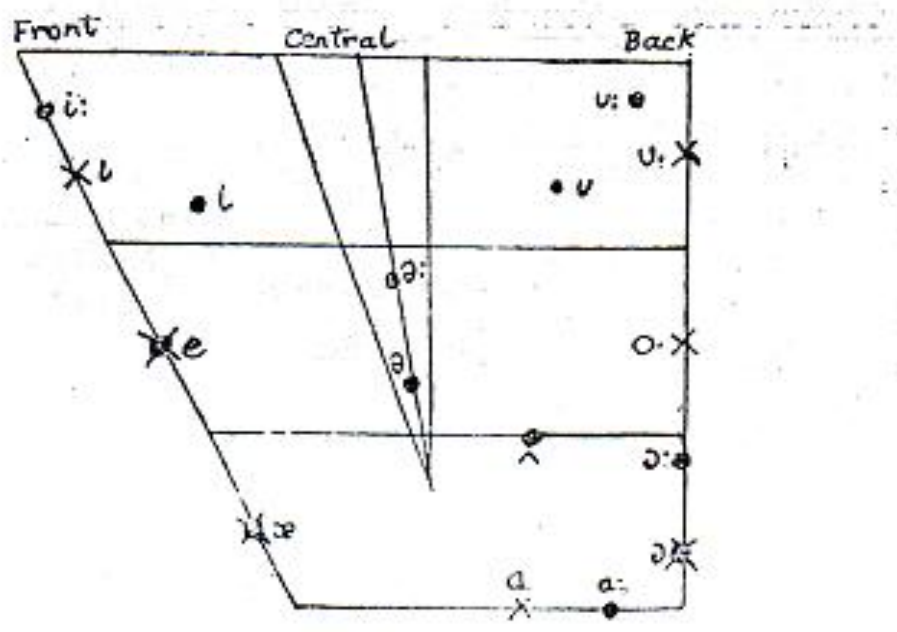

- English vowels.

$x$ Bengali vowels:

it English and Bengali vowels pronounced alike (only e and a )

From the above table, it can be observed that only two vowels $(\boldsymbol{e}, \boldsymbol{a})$ are common in both languages, and $\mathbf{J}$ is very close to the English one and is accepted as similar. They have found that the Bengali speakers 
equate the 4 English sounds (u:, $\mathbf{M}, \mathbf{3} ;, \mathbf{z})$ with a simple Bengali sound (d). (Hai \& Ball: 8-10)

Bengali speakers, as they observed, do not make any distinction between the long and short vowels of English. Mostly they put their own vowels / i:, ur, $\mathbf{c} /$ instead of / i:, u:, a:/, as they pronounce feet /fi:t /, half / ha:f/, fool /fu:l/ and taught /to:t/ as /fitt/, / hap/, / phul// and $/ \mathbf{t o} \mathbf{t} /$ respectively. Again, they observed that in certain parts of Chittagong, Sylhet and Naokhali, an open variety between / e/ and / $\mathbf{0} /$ is used. The Bengalis use / $\boldsymbol{\pi} /$ instead of /a/ for initial sounds (as in 'above'/aebab/) and /a/ or / / / for medial \& final sounds( as in 'letter' /letar/ and 'forget' / pharget /) (Hai \& Ball: 30-31)

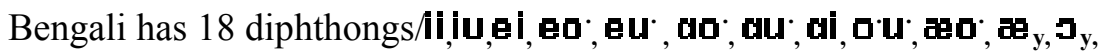
$\mathbf{0}_{\mathbf{y}}, \mathbf{a}_{\mathbf{y}}, \mathbf{0} \mathbf{0}, \mathbf{0} \mathbf{\mathbf { i }}, \mathbf{3 0}, \mathbf{u} \mathbf{i} /$ where there are only 8 in English / eı, $\mathbf{0 u}, \mathbf{a u}, \mathbf{J}$ I, al, Ia, ea, Ua /, but their characteristics are different. A common fault with some Bengali speakers of English is that they say only the first part of the diphthong and ignore the second part. Consequently, it appears as a short vowel. The formation of an English diphthong is a movement from one vowel position to another, but they stick at the first position (except al, aU and כו ) or pronounce the two vowels separately. Thus 'make'/meik/ is heard as $/ \mathbf{m e k} /$, 'boat'/bout/as/bu'l /, 'here' / hia/ as / hiar/, 'there' /מ̊pa/ as / Hersr/, etc. This substitution of one phoneme for another which is quite different is a major cause of confusion and misunderstanding. (Hai \& Ball: 11-12). They also break English diphthongs and pronounce as two separate sounds as in 'spoil'/spael/and 'toys'/taej/, or lengthen the first part somewhat, e.g. / $\mathbf{0} /$ instead of / ou/. So they pronounce 'no'/nou/ as $/ \mathbf{n o} \%$, 'low'/lou/ as /lo $/$ (Hai \& Ball: $31-32$ ).

Again, they have observed that English has 6 plosives (p, b, t, d, k, g ) as against 20 in Bengali (p, ph, b,bh, c,ch, k, kh, g, gh, t, th, d, dh, j, $\mathbf{j h}, \mathbf{t}, \mathbf{t h}, \mathbf{d}, \mathbf{d h})$. The sound $/ \mathbf{h} /$ is often confused by Bengali speakers, both in its medial and final positions, with the fricative sound $/ \mathbf{v} /$. Thus verb /va:b/ is pronounced as / bharv/, wave / weiv/ is pronounced as / $\mathbf{w e b} /$. The English sound /p/ is often pronounced as a fricative /f/ by the speakers of the south-eastern dialects of Bangla, especially the speakers of Noakhali. Thus 'put' / put / is pronounced as /fut / and 'sleep' /sli:p / as /slif/. (Hai \& Ball: 16-17)

Bengali plosive sounds, as they observed, may be grouped into five categories, each having four sounds distinguished from one another by 
the presence or absence of voice and aspiration. They are: 1) Velar /k(ক), $\mathbf{k h}($ খ), $\mathbf{g}($ গ), $\mathbf{g h}($ ঘ)/; 2) Alveolo-palatal /c(চ),ch(ছ), j(জ), jh(ঝ) /; 3) Alveo-retroflex /t(ট), th(ঠ), d(ऍ), dh(๖)/; 4) Dental /t(ত), th(থ), d(দ), dh(ধ) ; 5) Bilabial /p(প), ph(ফ), b(ব),bh (ভ)/. Here, the second and fourth sounds are strongly aspirated, and the first and third are unspirated. Similarly, the first and second are unvoiced whereas the third and fourth are voiced. In English, the unvoiced plosive sounds / $\mathbf{p}, \mathbf{t}, \mathbf{k}$ / are aspirated, especially when they occur at the beginning of a word, but this aspiration is not phonemic. Bengali / $\mathbf{p}, \mathbf{b}, \mathbf{t}, \mathbf{d}, \mathbf{k}, \mathbf{g}$ / are not at all aspirated. Unlike English, Bengali has aspirated counterparts for these, and this aspiration is phonemic and therefore differentiates the meaning of a word from its unaspirated counterpart. Bengali Alveolo-palatal sounds /c, $\mathbf{c h}, \mathbf{j}, \mathbf{j h} /$, unlike English, are more plosives than affricates. In south-east Bengal, these sounds $/ \mathbf{c}, \mathbf{c h}, \mathbf{j}, \mathbf{j h} /$ are pronounced as fricative sounds, but in the kutti dialect of Dhaka, these are found to be more affricate than plosive or fricative, much like English $/ \mathbf{t} \mathbf{J} /$ and $/ \mathbf{d} \mathbf{z} /$. The unvoiced velar aspirated plosive / kh (খ) / is a fricative sound in Chittagong and Sylhet. In Noakhali dialect, the bilabial plosive / $\mathbf{p} /$ is not heard at all, but replaced by a fricative sound similar to English /f/. (Hai \& Ball: 18- 20)

They have shown that there are no fricative sounds in Bengali which compare well with English fricatives / $\mathbf{f}, \mathbf{Y}, \mathbf{\theta}, \mathbf{0}, \mathbf{s , \mathbf { z }} / \mathbf{z} / \mathbf{z}$ is heard in Bengali words borrowed from English and words of Perso- Arabic origin. Bengali speakers find the sound /f/ difficult. They generally substitute for it the aspirated plosive / $\mathbf{p h}^{\mathbf{h}}$ (ফ)/ of their own language. Thus five /falv/ is heard as /phalb/, full / ful / as /phul /, etc. Bengali speakers often make the sound $/ \mathbf{\theta} /$ into an aspirated plosive $/ \mathbf{t h}($ ข)/, so thin /Bin/ and tin /tin/ sound the same to a foreign listener. They use a voiced aspirated bilabial plosive / bh (ভ)/ in place of $/ \mathbf{v} /$ (Hai \& Ball: 34 ). They also often confuse /s/ with / [/. In Bengali, there are 3 letters for these sounds (শ, ষ, স), but there are only two sounds. The sound $/ \mathbf{s} /$ is found in some foreign loan words and in particular contexts, for example, before the dental plosives and $/ \mathbf{r}, \mathbf{I}, \mathbf{n} /$ as in 'aste' (slowly), 'astha' (faith), 'sri' (Mr.), etc. Bengali Muslims always pronounce, 'Islam' correctly with the /5/ sound.(Hai \& Ball: 21-23).

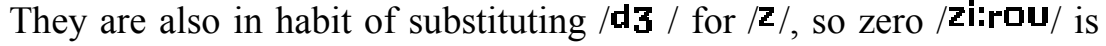
heard as /dziro/(Hai \& Ball: 35). Bengali speakers give two taps in pronouncing $/ \mathbf{r} /$. In addition, they never drop a final $/ \mathbf{r} /$, whereas it is normally dropped by English speakers, unless followed by a word starting with a vowel. (Hai \& Ball: 23) 
The Bengali speakers, as they have observed, face problems with Affricates $/ \mathbf{t} \mathbf{J} /$ and $/ \mathbf{d} \mathbf{3} /$, because standard Bengali has no affricate sound which compares well with those of English. It is only in the kutti dialect of Dhaka that sounds approximate to English affricates. In other places, particularly in Noakhali, these sounds are neither plosives nor affricates but fricatives. So the English affricates represented by/t $\mathbf{~}$ / and /dz/ in words like chair /t Jea/, church /t Ja:t J/, June /dzu:n/ etc. are not correctly pronounced by Bengali speakers. They pronounce them with much less affrication, if they are the speakers of standard Bengali and as fricatives if they are the speakers of south eastern dialect, e.g. in the dialect of Noakhali. They use $/ \mathbf{5} /$ instead of $/ \mathbf{t} \mathbf{J} /$. (Hai \& Ball: 26, 36)

Consonant clusters are also found problematic in the pronunciation of Bengali speakers. Thus the speakers of Noakhali and some other speakers in adjacent districts who cannot distinguish between $/ \mathbf{p} /$ and $/ \mathbf{f} /$ pronounce 'please' and 'fleas' alike. In the following cases of consonant clusters, Hai and Ball (1961) find the mispronunciation of the Bengali speakers in many cases. Some of them are as follows:

1. Aspiration of the plosives / p, t,d , / leads to confusion, as for example:

Supper-suffer, three-tree, through-true etc.

2. Final and medial $/ \mathbf{f t} /, / \mathbf{u d} /$ and $/ \mathbf{p} /$. The examples of this type of confusion are:

Lift- lived, gulf- gulp, etc.

3. Final -nd, nt may lead to confusion:

Found-fount.

Pined-pint.

4. There is a tendency to precede the clusters $s k$, $s t$ and $s p$ with an indeterminate vowel

School is heard as /iskul//

Spoon is heard as / ispun/

Station is heard as /iste Jan/ (37-41)

In finding out difficulties faced by the Bangladeshi speakers of English, Rahman (1995) has found that in Bangladesh, English is spoken with an accent related to the mother tongue which pays little attention to the sound patterns, stress, rhythm and intonation systems of English (1). Bengali speakers do not usually make any distinctions 
between short and long vowels. For example, they pronounce /ful/ and /fu:I/ in the same way. He also observes that the chief difficulty for a Bengali learner is using the weak forms $/ \mathbf{a} /$ and $/ \mathbf{I} /$ in unstressed syllables. This is not usually observed by a Bengali speaker (8).

Banu (2000) has found the Bangladeshi English as a new variety. She has drawn some obvious phonological distinctions of the Bangladeshi speakers of English which are as follows:

\section{Vowel system}

- Diphthongs /er/ and /au/ of BRP (British Received Pronunciation) are replaced by monopthongs /e:/ and /0:/ though there is a tendency to lengthen these monopthongs. For example, day /de:/, say /se:/, hate /he:t/, float/flo:t/, etc.

- The BRP central vowels / $\mathbf{m} /$ in words like bus, mother, cut, hut are made more lax and open and the result is almost like an /a/ like bas, kat, madar, hat.

- The BRP /a:/ in word like bird, girl, etc. are transformed into lax /a/ and /bard/ and /garl/ become homophonous with middle vowel of smart and heart.

\section{Consonant System}

The Bangladeshi English, the consonant system depends heavily on the features of aspiration, with a tendency to substitute some unaspirated English consonants with aspirated sounds. English fricatives $/ \mathbf{f}, \mathbf{\theta}, \mathbf{\mathbf { 0 }}, \mathbf{v}, \mathbf{z}, \mathbf{z} /$ are absent from the Bangla inventory of phonemes. In order to produce these new sounds, a typical Bangladeshi tends to use some of the native correspondences in his own language Bangla, and thus the mother tongue pull of aspirated stops becomes obvious. Thus/f/ becomes $/ \mathbf{p h} /, / \mathbf{\theta} /$ becomes/th/, /z/ becomes $/ \mathbf{d} /, / \mathbf{z} /$ becomes $/ \mathbf{d} \mathbf{z} /$ and $/ \mathbf{z} /$ becomes/ $\mathbf{3} /$ or $/ \mathbf{d} \mathbf{3} /$. Bangladeshi speakers realize $/ \mathbf{v} /$ as $/ \mathbf{b}$ $\mathbf{h} /$, a bilabial aspirated stop is very common. For example, loving / I $\mathbf{n b}$

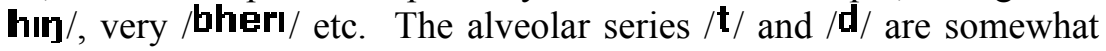
retroflexed by Bangladeshis, especially those from the south. The $/ \mathbf{z} /$ becomes / d $\mathbf{3} /$ and $/ \mathbf{d} \mathbf{3} /$ becomes $/ \mathbf{z} /$, so we hear zoo like jew or giraffe as ziraffe. She added that in standard BRP the stress patterns vary according to classes of words, e.g., nouns, verbs, adjectives, or follow rules of penultimate or ultimate syllables for compounds with many syllables. Bengali rhythm, on the other hand, is based on arranging long and short syllables, not stressed and unstressed ones. Thus there is 
more of a spelling pronunciation amongst Bangladeshi speakers of English. (64-65)

Muzaffar's (1999) study has pointed out some mispronunciation of some consonant sounds of Bangladeshi speakers of English like /f/ and $/ \mathbf{v} / ; / \mathbf{z} /, / \mathbf{d} \mathbf{z} /$ and $/ \mathbf{3} / ; / \mathbf{\theta} /$ and $/ \mathbf{z} / ; / \mathbf{t} /$ and $/ \mathbf{d} /$, etc. He has observed that students commonly adopt the labio-dentals $/ \mathbf{f} /$ and $/ \mathbf{v} /$ as the bilabial aspirated plosives $/ \mathbf{p}^{\mathbf{h}} /$ and $/ \mathbf{b}^{\mathbf{h}} /$, even some speakers adopt them as bilabial plosives $/ \mathbf{p} /$ and $/ \mathbf{b} /$. The reason of this mispronunciation, he thinks, is due to the absence of them from the Bangla phonemic inventory. Again he observes that Bangladeshi speakers pronounce the voiced palatal plosive $/ \mathbf{z} /$ and the voiced palato-alveolar affricate $/ \mathbf{d} \mathbf{3} /$ as allophones of the same phoneme. And they read the letter ' $z$ ' as $/ \mathbf{d} \mathbf{z} /$ and the letter ' $\mathrm{j}$ ' as $/ \mathbf{z} /$. He again finds that the voiceless aspirated dental plosives $/ \mathbf{\theta} /$ and $/ \mathbf{0} /$ tend to be the voiced dental plosive $/ \mathbf{t h} /$ and $/ \mathbf{u}_{(\overline{5}} /$ to the Bengali speakers. He also finds that Bengali students have problems with consonant clusters/sp/, $/ \mathbf{s t} /$ and $/ \mathbf{s m} /$. These are dealt with by the prothesis or epenthesis of a glottal stop or a vowel. (69-71)

From Hai and Ball, the study receives much information about L1 interference of the Bangladeshi speakers of English. But their observation is of a much earlier period (1961). Many changes occurred after that observation. Moreover, the observation is a general study of all Bangladeshi speakers. From Muzaffar's study, this study has benefited much. Still much observation is needed. Other studies have only shown the references of other studies, and do not refer to any information of the influence of local varieties of Bangladeshi speakers of English. So, considering the above studies the incomplete ones, this study explores the interference of local varieties in the sound patterns of English of Bangladeshi speakers.

\section{Methodology}

As the requirement of the study, the researcher followed a qualitative approach.

A total of 88 undergraduate students from different semesters of two departments of a university in Dhaka are selected for this study. As most of them are the students of English department, and many of them have already completed more than one semester of their tertiary level education, they are likely to have enough exposure to the spoken English. But they are not good at standard spoken English because of 
their socio-cultural backgrounds and their familiarity with substandard pronunciation of English in their rural life education for about twelve years.

\section{Three techniques have been followed for data collection.}

1. A population of students of different semesters $\left(1^{\text {st }}-7^{\text {th }}\right)$ of two departments have been randomly chosen on the basis of the varieties of their regions. They have been asked to pronounce some commonly used English (often mispronounced) words written on the board, and they have been recorded and written with IPA transcription. The randomly chosen words are class, today, department, flower, paper, professor, victory, effective, glass, very, zoo, flask, semester, risk, zero, spring, special, little etc.

\begin{tabular}{|c|c|c|c|c|}
\hline$\cdot \frac{\pi}{\pi}$ & $\begin{array}{l}\overrightarrow{\vec{D}} \\
\stackrel{\vec{D}}{\vec{n}}\end{array}$ & department & $\begin{array}{l}\text { village/ } \\
\text { upozila/ } \\
\text { thana/ } \\
\text { District/town }\end{array}$ & Words with transcription \\
\hline 1. & $\begin{array}{l}\mathrm{F} \\
5^{\text {th }}\end{array}$ & $\begin{array}{l}\text { English } \\
\text { Language } \\
\& \\
\text { Literature }\end{array}$ & $\begin{array}{l}\text { Shibchor, } \\
\text { Madaripur }\end{array}$ & $\begin{array}{l}\text { Class / klns/, today / t } \\
\text { ude:/, department /difa } \\
\text { rment/, flower /plau } \\
\text { ar/, paper/pe:pnr/. }\end{array}$ \\
\hline 2. & $\mathrm{~J} 5^{\text {th }}$ & $\begin{array}{l}\text { English } \\
\text { Language\& } \\
\text { Literature }\end{array}$ & Feni & $\begin{array}{l}\text { Glass /glns/, paper /p } \\
\text { e:pm r/,flower/flauer/, } \\
\text { professor/prbf's br } \\
\text { /,department/difarmen } \\
\mathbf{t} / \text {. }\end{array}$ \\
\hline 3. & $\begin{array}{l}P \\
5^{\text {th }}\end{array}$ & $\begin{array}{l}\text { English } \\
\text { Language\& } \\
\text { Literature }\end{array}$ & $\begin{array}{l}\text { Shenbag, } \\
\text { Noakhali }\end{array}$ & $\begin{array}{l}\text { Glass /glas/, flower/fl } \\
\text { auar/, professor/prof } \\
\text { esbr/, paper / peipn } \\
\mathbf{r} / \text {,today/tude/,effective } \\
\text { /Ifektiv/, department/l } \\
\text { |pr:trtment/. }\end{array}$ \\
\hline 4. & $\mathrm{~J} 5^{\text {th }}$ & $\begin{array}{l}\text { English } \\
\text { Language\& } \\
\text { Literature }\end{array}$ & Natore & $\begin{array}{l}\text { Professor / profesnr/, } \\
\text { victory / blukLu:rı/. }\end{array}$ \\
\hline
\end{tabular}




\begin{tabular}{|c|c|c|c|c|}
\hline 5. & $\mathrm{~N}^{\text {th }}$ & $\begin{array}{l}\text { English } \\
\text { Language\& } \\
\text { Literature }\end{array}$ & $\begin{array}{l}\text { Polash, } \\
\text { Norshingdi }\end{array}$ & $\begin{array}{l}\text { Class /klns/, flower/fl } \\
\text { auar/, professor/p } \\
\text { hrofesnr/, effective/ıf } \\
\text { ektiv/, department /لlı } \\
\text { phntment/ }\end{array}$ \\
\hline 6. & $\begin{array}{l}M \\
5^{\text {th }}\end{array}$ & $\begin{array}{l}\text { English } \\
\text { Language\& } \\
\text { Literature }\end{array}$ & $\begin{array}{l}\text { Laksham, } \\
\text { Comilla }\end{array}$ & 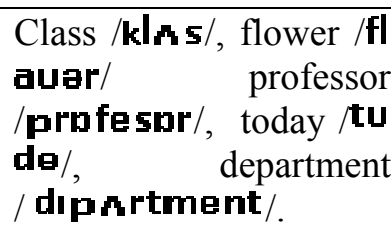 \\
\hline 7. & $\begin{array}{l}\mathrm{A} \\
5^{\text {th }}\end{array}$ & $\begin{array}{l}\text { English } \\
\text { Language\& } \\
\text { Literature }\end{array}$ & Norshingdi & $\begin{array}{l}\text { Class /klns/, flower/fl } \\
\text { auar/, professor /prpf } \\
\text { es br/,today/tude/, } \\
\text { department/dip } \\
\text { nt/,effective / Ifektiv/. }\end{array}$ \\
\hline 8. & $\begin{array}{l}\mathrm{R} \\
5^{\text {th }}\end{array}$ & $\begin{array}{l}\text { English } \\
\text { Language\& } \\
\text { Literature }\end{array}$ & $\begin{array}{l}\text { Porshuram, } \\
\text { Feni }\end{array}$ & $\begin{array}{l}\text { Class /klns/, flower / } \\
\text { flauar/, professor /pr } \\
\text { ofesmr/, today /tude/, } \\
\text { department /dip } \mathbf{n r t m} \\
\text { ent/,effective/ıfaktıv/. }\end{array}$ \\
\hline 9. & $\begin{array}{l}M \\
5^{\text {th }}\end{array}$ & $\begin{array}{l}\text { English } \\
\text { Language\& } \\
\text { Literature }\end{array}$ & $\begin{array}{l}\text { Shamnogor, } \\
\text { Sathkhira }\end{array}$ & $\begin{array}{l}\text { Class /klms/, flower } / \mathbf{f} \\
\text { lauar/, professor } \\
\text { /profespr/, today /tu } \\
\text { de/, department /dı } \\
\text { paitment/,effective /ı } \\
\text { fektıu/. }\end{array}$ \\
\hline 10. & $\begin{array}{l}\mathrm{A} \\
3^{\mathrm{rd}}\end{array}$ & $\begin{array}{l}\text { English } \\
\text { Language\& } \\
\text { Literature }\end{array}$ & $\begin{array}{l}\text { Dhunot, } \\
\text { Bogra }\end{array}$ & $\begin{array}{l}\text { Class /klns/, flower } / \mathbf{f} \\
\text { leuar/, professor /prnf } \\
\text { espr/, today /tude/, } \\
\text { department /dipnrtm } \\
\text { ent/. }\end{array}$ \\
\hline 11. & $\mathrm{~S}^{\text {rd }}$ & $\begin{array}{l}\text { English } \\
\text { Language\& } \\
\text { Literature }\end{array}$ & $\begin{array}{l}\text { Laksham, } \\
\text { Comilla }\end{array}$ & $\begin{array}{l}\text { Class / klms/, flower/fl } \\
\text { aug(r)/, professor /pro } \\
\text { fespr/,today/tudei/, } \\
\text { department/dipd:tme } \\
\text { nt/. }\end{array}$ \\
\hline
\end{tabular}




\begin{tabular}{|c|c|c|c|c|}
\hline 12. & $\begin{array}{l}\mathrm{U} \\
3^{\text {rd }}\end{array}$ & $\begin{array}{l}\text { English } \\
\text { Language\& } \\
\text { Literature }\end{array}$ & $\begin{array}{l}\text { Kuliarchor, } \\
\text { Kishoregonj }\end{array}$ & $\begin{array}{l}\text { Class /klns/, flower /f } \\
\text { louer/, professor/prof } \\
\text { esnr/, today/tude/, } \\
\text { department/dipartme } \\
\mathbf{n t} / .\end{array}$ \\
\hline 13. & $\mathrm{~J} 3^{\text {rd }}$ & $\begin{array}{l}\text { English } \\
\text { Language\& } \\
\text { Literature }\end{array}$ & $\begin{array}{l}\text { Nobinogor, } \\
\text { B Baria }\end{array}$ & $\begin{array}{l}\text { Class /klas/, flower/fl } \\
\text { auar/, professor/Prof } \\
\text { esvr/, today/tude/, } \\
\text { department /dipntme } \\
\text { mL/, effective / Ifektı// }\end{array}$ \\
\hline 14. & A $3^{\text {rd }}$ & $\begin{array}{l}\text { English } \\
\text { Language\& } \\
\text { Literature }\end{array}$ & Gaibanda & $\begin{array}{l}\text { Class /klıs/, flower } / \mathbf{f l} \\
\text { aua(r)/, professor } \\
\text { /profespr/, today /tu } \\
\text { de/, department /di } \\
\text { pa:rtment/. }\end{array}$ \\
\hline 15. & $\mathrm{H} 3^{\text {rd }}$ & $\begin{array}{l}\text { English } \\
\text { Language } \\
\& \\
\text { Literature }\end{array}$ & $\begin{array}{l}\text { Mothbaria, } \\
\text { Pirojpur }\end{array}$ & $\begin{array}{l}\text { Class /klns/, flower } / \mathbf{f l} \\
\text { aua(r)/, professor } \\
\text { /prore:sor/, today /tu } \\
\text { de/, department /dipa } \\
\text { :rtment/. }\end{array}$ \\
\hline 16. & $\begin{array}{l}\mathrm{M} \\
3^{\mathrm{rd}}\end{array}$ & $\begin{array}{l}\text { English } \\
\text { Language } \\
\& \\
\text { Literature }\end{array}$ & Jhenaidah & $\begin{array}{l}\text { class /k|As/, flower } / \mathbf{f l} \\
\text { auar/, professor /prnf } \\
\text { esvr/, today /tudel/, } \\
\text { department /dipntme } \\
\mathbf{n t} / \text {. }\end{array}$ \\
\hline 17. & $\mathrm{~S} 2^{\text {nd }}$ & $\begin{array}{l}\text { English } \\
\text { Language } \\
\& \\
\text { Literature }\end{array}$ & $\begin{array}{l}\text { Vanga, } \\
\text { Faridpur }\end{array}$ & $\begin{array}{l}\text { Class /kI } \mathbf{n s} /, \text { flower } / \mathbf{f l} \\
\text { aua(r)/, professor } \\
\text { /prbfe:sor/, today/tu } \\
\text { del/, department/dı } \\
\text { pa:tment/,effective / } \\
\text { Ifektıv/. }\end{array}$ \\
\hline 18. & $\mathrm{~J} 4^{\text {th }}$ & $\begin{array}{l}\text { English } \\
\text { Language } \\
\& \\
\text { Literature }\end{array}$ & $\begin{array}{l}\text { Gurudashpur, } \\
\text { Natore }\end{array}$ & $\begin{array}{l}\text { Professor / profhesnr } \\
\text { /, victory /bhiktori/, } \\
\text { flower /flauar/, paper } \\
\text { /peipnr/. }\end{array}$ \\
\hline 19. & $\mathrm{~B} 4^{\text {th }}$ & $\begin{array}{l}\text { English } \\
\text { Language }\end{array}$ & Chouddho- & $\begin{array}{l}\text { Flower / plauar/, } \\
\text { professor / probhes }\end{array}$ \\
\hline
\end{tabular}




\begin{tabular}{|c|c|c|c|c|}
\hline & & $\begin{array}{l}\& \\
\text { Literature }\end{array}$ & gam, Comilla & $\begin{array}{l}\mathbf{r} / \text {, department/difarm } \\
\text { ent/,effective / aefektı } \\
\mathbf{y} / \text {, very/ be:ri/, victory } \\
\text { /bıkturi/. }\end{array}$ \\
\hline 20. & $\mathrm{~F} 7^{\text {th }}$ & $\begin{array}{l}\text { English } \\
\text { Language } \\
\& \\
\text { Literature }\end{array}$ & Meherpur & $\begin{array}{l}\text { Class / klms/, professor } \\
\text { / profesbr/, flower/fl } \\
\text { auar/, paper/paep } \mathbf{m r} / \text {, } \\
\text { today/tude/. }\end{array}$ \\
\hline 21. & A $7^{\text {th }}$ & $\begin{array}{l}\text { English } \\
\text { Language } \\
\& \\
\text { Literature }\end{array}$ & $\begin{array}{l}\text { Meghna, } \\
\text { Comilla }\end{array}$ & 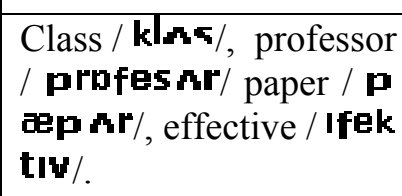 \\
\hline 22. & $\mathrm{~A} 7^{\text {th }} /$ & $\begin{array}{l}\text { English } \\
\text { Language } \\
\text { \& } \\
\text { Literature } \\
\end{array}$ & $\begin{array}{l}\text { Pathorghata, } \\
\text { Borguna }\end{array}$ & $\begin{array}{l}\text { Class / klas/, professor } \\
\text { / profesa(r)/ paper / } \\
\text { pelpar/. }\end{array}$ \\
\hline 23. & $\begin{array}{l}\mathrm{M} \\
7^{\text {th }}\end{array}$ & $\begin{array}{l}\text { English } \\
\text { Language } \\
\& \\
\text { Literature }\end{array}$ & $\begin{array}{l}\text { Gumostapur, } \\
\text { Chapai }\end{array}$ & $\begin{array}{l}\text { Class / klas/, paper / } \mathbf{p} \\
\operatorname{app} \mathbf{n r} / .\end{array}$ \\
\hline 24. & $\begin{array}{l}M \\
7^{\text {th }}\end{array}$ & $\begin{array}{l}\text { English } \\
\text { Language } \\
\& \\
\text { Literature }\end{array}$ & $\begin{array}{l}\text { Chouddhogrm } \\
\text { Comilla }\end{array}$ & $\begin{array}{l}\text { Class / klıs/, professor } \\
\text { / pro:fesa(r)/, paper / } \\
\text { paepa(r)/, effective / I } \\
\text { fektiv/, flower /flaua } \\
(\mathbf{r}) / \text {. }\end{array}$ \\
\hline 25. & $\mathrm{~A} 1^{\mathrm{st}}$ & $\begin{array}{l}\text { English } \\
\text { Language\& } \\
\text { Literature }\end{array}$ & $\begin{array}{l}\text { Kaligonj, } \\
\text { Gazipur }\end{array}$ & $\begin{array}{l}\text { zoo / dzü/, glass / yln } \\
\text { s/, flower / flauar/, } \\
\text { professor / pro resor/ } \\
\text { flask / fln } \mathbf{\int k} \text {. }\end{array}$ \\
\hline 26. & $\mathrm{~A} 1^{\mathrm{st}}$ & $\begin{array}{l}\text { English } \\
\text { Language } \\
\& \\
\text { Literature }\end{array}$ & $\begin{array}{l}\text { Sonagazi, } \\
\text { Feni }\end{array}$ & $\begin{array}{l}\text { zoo / dzü /, glass / qla } \\
\text { s/, flower / flauar/, } \\
\text { professor / profe:sor/, } \\
\text { flask / flnsk/. }\end{array}$ \\
\hline 29. & $\mathrm{~S} 1^{\mathrm{st}}$ & $\begin{array}{l}\text { English } \\
\text { Language } \\
\& \\
\text { Literature }\end{array}$ & $\begin{array}{l}\text { Kathalia, } \\
\text { Jhalokathi }\end{array}$ & $\begin{array}{l}\text { Zoo / zuः/, glass / glas } \\
\text { /, flower / flaugr/, } \\
\text { professor / profe:sor/, } \\
\text { flask / flnsk/. }\end{array}$ \\
\hline
\end{tabular}




\begin{tabular}{|c|c|c|c|c|}
\hline 30. & $\mathrm{E} 1^{\mathrm{st}}$ & $\begin{array}{l}\text { English } \\
\text { Language } \\
\& \\
\text { Literature }\end{array}$ & $\begin{array}{l}\text { Hossenpur, } \\
\text { Kishoregonj }\end{array}$ & $\begin{array}{l}\text { Zoo /dzü/, glass / gln } \\
\text { s/, flower /flaue(r)/, } \\
\text { professor / profes } \mathbf{m r} / \\
\text { flask / fln sk/. }\end{array}$ \\
\hline 31. & $\underset{1}{\mathrm{O}}$ & $\begin{array}{l}\text { English } \\
\text { Language } \\
\& \\
\text { Literature }\end{array}$ & $\begin{array}{l}\text { Laksham, } \\
\text { Comilla }\end{array}$ & $\begin{array}{l}\text { zoo /dzü/, glass / qla } \\
\text { s/, flower / plauar/, } \\
\text { professor / probe:spr/, } \\
\text { flask / flnsk/. }\end{array}$ \\
\hline 32. & $\mathrm{~T} 1^{\mathrm{st}}$ & $\begin{array}{l}\text { English } \\
\text { Language } \\
\& \\
\text { Literature }\end{array}$ & Nilfamari & $\begin{array}{l}\text { zoo / dzü/, glass / gla } \\
\text { s/, flower / flauar/, } \\
\text { professor / pro:fesor/, } \\
\text { flask / flnsk/. }\end{array}$ \\
\hline 33. & $\mathrm{~F}$ & $\begin{array}{l}5^{\text {th }} / \text { English } \\
\text { Language } \\
\& \\
\text { Literature }\end{array}$ & $\begin{array}{l}\text { Shenbag, } \\
\text { Noakhali }\end{array}$ & $\begin{array}{l}\text { class } / \text { klns/, } \\
\text { professor / profesnr/, } \\
\text { paper / pepnr/, } \\
\text { effective/lfektiv/, } \\
\text { flower/flauar/, } \\
\text { department /dipntme } \\
\mathbf{n t} / \text {. }\end{array}$ \\
\hline 34. & $\mathrm{~S}$ & $\begin{array}{l}5^{\text {th }} / \text { English } \\
\text { Language } \\
\& \\
\text { Literature }\end{array}$ & $\begin{array}{l}\text { Shampur, } \\
\text { Dhaka }\end{array}$ & 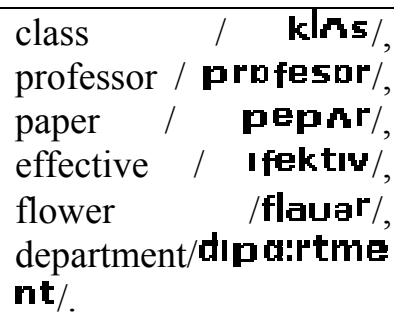 \\
\hline 35. & $\mathrm{~S} 5^{\text {th }}$ & $\begin{array}{l}\text { English } \\
\text { Language } \\
\& \\
\text { Literature }\end{array}$ & $\begin{array}{l}\text { Pakundia, } \\
\text { Mymensingh }\end{array}$ & $\begin{array}{l}\text { class / klns/, professor } \\
\text { / profesar/, paper / p } \\
\text { epar/, semester / sem } \\
\text { istar/, flower / flauar } \\
\text { /, department /dipart } \\
\text { ment/. }\end{array}$ \\
\hline 36. & $\mathrm{~S} 5^{\text {th }}$ & $\begin{array}{l}\text { English } \\
\text { Language } \\
\& \\
\text { Literature }\end{array}$ & Cox'sBazar & $\begin{array}{l}\text { class / klns/, professor } \\
\text { / profesnr/, flask / fl } \\
\text { aks/, semester / semı } \\
\text { star/, flower / flauar/, }\end{array}$ \\
\hline
\end{tabular}


IIUC Studies, Vol. 7

\begin{tabular}{|c|c|c|c|c|}
\hline & & & & risk / riks/. \\
\hline 37. & $\mathrm{H} 5^{\text {th }}$ & $\begin{array}{l}\text { English } \\
\text { Language } \\
\& \\
\text { Literature }\end{array}$ & $\begin{array}{l}\text { Mirzagonj, } \\
\text { Borishal }\end{array}$ & $\begin{array}{l}\text { Flask / flaks/, semester } \\
\text { / semistar/, risk / riks } \\
\text { /, department /dipnrt } \\
\text { ment/. }\end{array}$ \\
\hline 38. & $\mathrm{~N} 5^{\text {th }}$ & $\begin{array}{l}\text { English } \\
\text { Language } \\
\& \\
\text { Literature }\end{array}$ & $\begin{array}{l}\text { Alamdanga, } \\
\text { Kustia }\end{array}$ & $\begin{array}{l}\text { flask / flaks/, semester } \\
\text { / semıst } \mathbf{n r} \text { /, risk } \\
\text { / rısk/, zero / dzıru/. }\end{array}$ \\
\hline 39. & $\mathrm{~S} 5^{\text {th }}$ & $\begin{array}{l}\text { English } \\
\text { Language } \\
\& \\
\text { Literature }\end{array}$ & Thakurgaon & $\begin{array}{l}\text { Flask / flmsk/, semester } \\
\text { / semıstmr/, zero /zır } \\
\text { u/, paper / pelpar/. }\end{array}$ \\
\hline 40. & $\mathrm{R} 5^{\text {th }}$ & LLB & Laksmipur & $\begin{array}{l}\text { flask/flnsk/, spring / IS } \\
\text { prin /, special / Ispae 【 } \\
\text { al /, zero / dziru/, } \\
\text { professor / profespr/. }\end{array}$ \\
\hline 41. & $\mathrm{~K}^{\text {th }}$ & LLB & $\begin{array}{l}\text { Maijdi, } \\
\text { Noakhali }\end{array}$ & $\begin{array}{l}\text { flask / Ilmsk/, spring / } \\
\text { sprin /, special/ spe: I } \\
\mathbf{A l} \text { /, zero / ziru/, } \\
\text { professor / profe sor/. }\end{array}$ \\
\hline 42. & I $5^{\text {th }}$ & LLB & $\begin{array}{l}\text { Begumgonj, } \\
\text { Noakhali }\end{array}$ & $\begin{array}{l}\text { flask / fla:sk/, special/ } \\
\text { spe:[ml/, zero /dzaer } \\
\text { u/, glass / glas/, } \\
\text { department /dipartm } \\
\text { ent/. }\end{array}$ \\
\hline 43. & $\mathrm{~N} 5^{\text {th }}$ & LLB & Sathkhira & 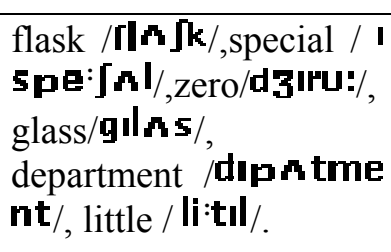 \\
\hline 44. & $\begin{array}{l}M \\
5^{\text {th }}\end{array}$ & LLB & $\begin{array}{l}\text { Muradnogor, } \\
\text { Comilla }\end{array}$ & 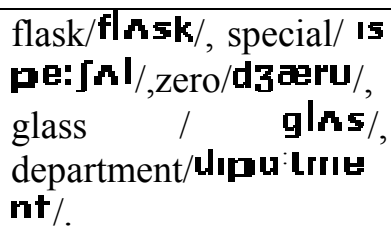 \\
\hline
\end{tabular}




\begin{tabular}{|c|c|c|c|c|}
\hline 45. & $\mathrm{M} 5^{\text {th }}$ & LLB & $\begin{array}{l}\text { Neamatpur, } \\
\text { Nougaon }\end{array}$ & 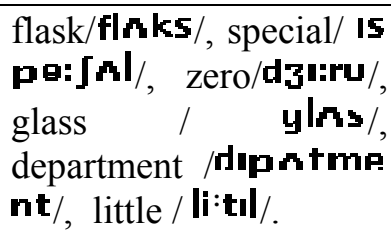 \\
\hline 46. & $\mathrm{R} 4^{\text {th }}$ & LLB & Netrokona & 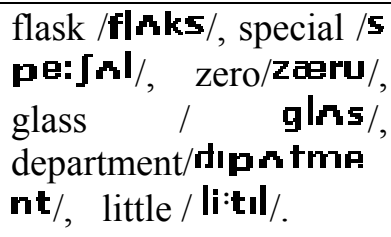 \\
\hline 47. & $\mathrm{~B} 4^{\text {th }}$ & LLB & $\begin{array}{l}\text { Moheshpur, } \\
\text { Jhenaidah }\end{array}$ & 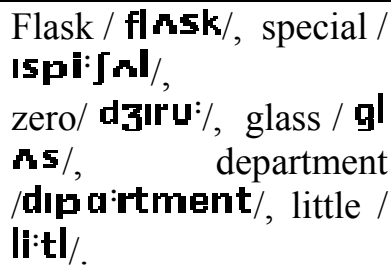 \\
\hline
\end{tabular}

2. Another group of student-participants have been asked to read some passages, and some words of problematic pronunciation have been written from the record, e.g. 'table' /te:bvl/, study /Is.tadı/, 'against'/ age:nest/, 'thank'/taenk/, 'good'/gut/, 'suicide' / sus eId/, etc.

3. The other students have been engaged in dialogues. From the dialogues, the words like 'teacher'/tissmr/, 'study'/asstndI/ or /ISt adı/, 'district'/dıstık/, 'exam'/ıgzam/, etc. have been identified.

The student-participants are different from each other with regard to their socio- cultural and educational backgrounds. Though they commonly share some broad similarities such as having the same first language, i.e. Bangla, they have their own local varieties.

Before the interview, the participants have been assured of the fact that no harm will be done to them, and their privacy will be strictly maintained by the researcher. Accordingly, the study used the first letters of their names. This helped the participants feel free and comfortable in facing the interview. 


\section{Data Analysis}

It is observed that when a student of rural background utters the speech sounds of standard Bangla, they cannot come out of the influence of local varieties, and it has its consequent effect on their utterance of English sounds. So they face the following problems when they speak in English.

\section{Problem with long and short vowels}

A common fault with some Bengali speakers of English, as Hai and Ball (1961) observed, is to say only the first part of the diphthong and ignore the second part. Consequently, it appears as a short vowel. Bengali speakers do not make any distinction between the long and short vowels of English.(11) This study has found that 12 out of 22

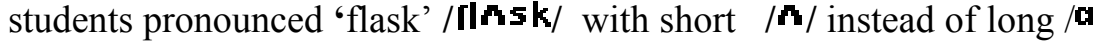
$: /$.

Rahman (1996) also has noted that the quality of a Bangla vowel is not conditioned by length. On the other hand, length distinguishes English vowel sounds /I, i:, v, J:, u, u:/ (8). Unawareness of this distinction may be observed in the pronunciation of 'department' / ل/p mtment/ by almost 5 out of 26 students. The participants were from Noakhali, Satkhira, Netrokona, Naogaon and Jhenaidah. A number of students from several other regions like Hobigonj, Borishal, Vhola, Mymensingh, Bogra, Feni, Noakhali, Norshinghdi and Comilla pronounced the same word as /dipmrtment/ with short $/ \mathbf{m} /$. Some other pronounced/diphntment/.

\section{Problem with diphthongs}

Again, some learners of English cannot pronounce diphthongs properly. In most cases, they pronounce the first part of diphthong, and prolong it. We can observe the pronunciation of 'paper', which has been pronounced as /pr:pnr/ instead of/ pripa(r)/, and some students make it a monophthong with pronouncing the first part / pep $\mathbf{M r}$ /. D from Feni pronounced 'suicide' / Sulsald/ as / Suseld/. Banu (2000) has observed the fact, as she says, "diphthongs /eI/ and /au/ of BRP (British Received Pronunciation) are replaced by monophthongs /e:/ and /0:/ with a tendency to lengthen these monopthongs, e.g. day $/$ de:/, say $/$ se:/, hate /he:t/, etc. (64).

Problem with fricative / $/$ / and $/ \mathbf{v} /$ sounds

Some students of rural background interchange the pronunciation of bilabial plosive $/ \mathbf{p} /$ and fricative $/ \mathbf{f} /$. For example, $\mathbf{C}$, a student from 
Shibchor (Madaripur), E, a student from Chouddhogram (Comilla), I from Laksham (Comilla) pronounced 'flower'/flaua(r)/ as /plauar/. Similarly, bilabial / $\mathbf{v} /$ and plosive $/ \mathbf{b} /$ are interchanged by some rural students. A student from Comilla pronounced 'very' / veri/ as /be:rı/, 'victory'/vıktari/ as /bıkturı/. A student from Natore pronounced the sound as $/ \mathbf{b h} /$ as he pronounced the word as /bhıkto:ri/.And this is the tendency of the most Bangladeshi speakers. The tendency of pronouncing /f/ as / b/ was also observed. For example, I from Laksham (Comilla) pronounced professor / prafese(r)/ as / probe:s nr/.

Sultana and Arif (2007) have also observed that the people hailing from Noakhali mix-up between the pronunciation of $\mathrm{P}$ and F. So when a person from this region reads PARTNER, he has to make sure of not reading it as FARTNER (p.137). It can be added here that people from Feni and Madaripur have also the same problem. J, a student from Feni and $\mathbf{F}$, a student from Shibchor, Madaripur; J, a student from B. Baria pronounced 'department' /dip a:tment/, as /difmrment/, and it was done by 4 out of 29 students.

\section{Problem with consonant clusters}

The sound of consonant clusters is also problematic for Bengali speakers. They put a short vowel within or before the consonant cluster. A, a student from Jhalokathi (Borishal); N, a student from Satkhira, pronounced 'glass'/glda:s/ as /gilms/, R, a student from

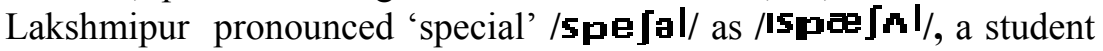
from Feni pronounced 'stupid'/stju:pld/ as /Istupld/ and a student from Borishal pronounced 'flower' / felauar/. Similarly, a student

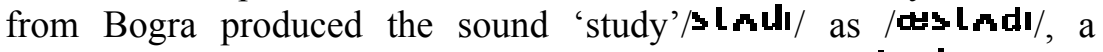
student from Chuadanga produced the same sound as /Ista dı/. F from Comilla, J from Khulna and $\mathbf{G}$ from Norshingdi pronounced 'against'/ ggeinst/ as / age:nest/, 'table'/teıbl/ as /te:bol/. A group of students from several regions like Netrokona, Naogaon, and Satkhira produced the consonant cluster $/ \mathbf{t l} /$ as / $\mathbf{t I l} /$ as in 'little' / li:tıl/ and a student from Sirajgonj pronounced it / litel/. The English speakers of some other regions like Borishal and Mymensingh omitted the second consonant from the consonant clusters like $/ \mathbf{p r} \mathbf{r}$ and $/ \mathbf{t r} /$. For example a student of Borishal pronounced 'professor' /prafesa(r)/ as $\mathbf{p ( r ) \mathbf { n f }}$ esvr/ and a student from Mymensingh pronounced district / distrikt / as /distık/. Consonant cluster/sk/ was pronounced as/ ks/ by almost 7 among 22 students from Cox'sBazar, Borishal, Vhola, Hobigonj, Kustia, Naogaon and Netrokona in the word 'flask', and 3 out of 4 
from Cox'sBazar, Borishal, Hobigonj pronounced the word 'risk' / ris $\mathbf{k} /$ as $/ \mathbf{r} \mathbf{l} \mathbf{k}$ /. Another student from Kustia pronounced 'flask' as $/ \mathbf{f l} \mathbf{n}$ $\mathbf{k} \mathbf{5}$ / but 'risk' as / risk/.

\section{Problem with $/ \mathbf{s} /$ sound}

From standard Bangla, /s/ sound is absent, though it is found in some regional varieties. So some Bangladeshi speakers cannot produce this sound, instead they utter $/ \mathbf{J} /$ sound. A student from Satkhira and another from Gazipur pronounced 'flask' / fla:sk/ as / fla $\mathbf{~} \mathbf{k} /$.

\section{Problem with $/ \mathbf{z} /$ and $/ \mathbf{t} /$ / sounds}

It is commonly found that Bengali speakers find problem with $/ \mathbf{z}$ / sounds. Muzaffar (1999) observes that there are many students who consistently read the letter ' $z$ ' as $/ \mathbf{d} \mathbf{3} /$ and the letter ' $j$ ' as $/ \mathbf{Z} /(70)$. Though he did not know any linguistic reason of it, it is to be observed that these sounds are absent from Bengali sounds, so Bengali speakers cannot pronounce it. But in some regions, / $/ \mathbf{L}$ sound is found. $\mathbf{K}$ from Noakhali pronounced 'zero'/zıarau/ or /Zi:rou/ as / Zıru/, and $\mathbf{R}$ from Netrokona uttered / zeru/. On the other hand, 8 out of 12 students produced the sound $/ \mathbf{d} \mathbf{3} /$ instead of $/ \mathbf{z} /$ in the word 'zero'. The most Bengali speakers have no problem with $/ \mathbf{t} \mathbf{J} /$ sound, because almost similar sound /c ( $\overline{(}) /$ is found in Bengali. But it is problematic to some speakers, e.g. A, a student from Noakhali, pronounced 'teacher'/ti:t $\int \mathbf{a} /$ as $/ \mathbf{t i} \mathbf{s} \mathbf{n} \mathbf{r} / . \mathbf{H}$ from Pirujpur and $\mathbf{M}$ from Borishal also produced the same sound in the same word.

\section{Problem with / $\mathbf{\theta} /$ sound}

Banu (2000) has an observation that for the Bengali speakers of English, / / / becomes /th/ (64). In this present study, it is also observed that for some speakers / $\mathbf{\theta} /$ becomes /t (ত)/. A from Jhalokati and $\mathbf{A}$ from Noakhali pronounced 'thank' / Bänk/ as /tänk/.

\section{Problem with /d/ sound}

This study observes that $/ \mathbf{d} /$ is pronounced as /t/ by some speakers. A student from Feni pronounced good /gud/ as /gut/.

\section{Results and discussion}

The study observes that the students who passed their SSC and HSC examinations from the villages are weaker in pronunciation than those who did them in home towns, and those who obtained their SSC and 
HSC or one of them in their respective towns outside Dhaka are weaker in pronunciation than those who did them in Dhaka.

It is also observed that the students who have been staying in Dhaka for a long time, though they obtained their SSC/HSC outside Dhaka are improving their pronunciation. We can have a look at the pronunciation of $\mathbf{A}$ from Borguna and $\mathbf{M}$ from Comilla, i.e. ( paper / peip Ar/) and ( effective / Ifektıv/, flower /flaue(r)/ ).

The sounds that have been found deviated from standard received pronunciation are summed up in the following sequence. Here the left hand side contains the English phoneme, and the right hand side indicates the pronunciation of the students and the symbol $(\sim)$ means 'is changed to'.

i) An English short vowel becomes a long one:

$$
\text { /e/ / /e:/ }
$$

ii) Some diphthongs become monopthongs or lengthened monopthongs:

$$
\begin{aligned}
& \text { /au/ / } \mathbf{a : / ~} \\
& \text { /el/ / } \mathbf{e : /}
\end{aligned}
$$

iii) Some labio-dental fricatives become bilabial plosive or bilabial aspirated plosive:

$$
\begin{gathered}
/ \mathbf{f} / \sim / \mathbf{p} / \\
/ \mathbf{f} / \sim / \mathbf{p}^{\mathbf{h}} / \\
/ \mathbf{v} / \sim / \mathbf{b} / \\
/ \mathbf{v} / \sim / \mathbf{b}^{\mathbf{h}} /
\end{gathered}
$$

iv) An alveolar fricative becomes a palato-alveolar fricative:

$$
\text { / } \mathbf{s} / \sim / \text { / }
$$

v) A voiced palatal plosive becomes a voiced palato-alveolar affricate or vice versa:

$$
\mid \mathbf{7} / \sim / \mathbf{d} \mathbf{3} /
$$

$$
/ \mathbf{d} \mathbf{3} / \sim / \mathbf{z} /
$$

vi) A dental fricative becomes a dental plosive: 


$$
\text { /日/ / } \mathbf{t} \text { (ত)/ }
$$

vii) An alveolar plosive becomes an alveo-retroflex plosive:

$$
/ \mathbf{d} / \sim / \mathbf{t} /
$$

\section{Pedagogical Implications}

The study was conducted to make the teachers aware of the problems of spoken English and how to develop this skill, so that teaching could aim at resolving some of these problems. Here are some suggestions which may be considered while teaching a language class.

1. As the teacher plays the role of a needs analyst, it is the primary responsibility of the teacher to find out why the students still have pronunciation problem though they have had exposure to English for about 12 years.

2. Enough time needs to be allocated for the spoken English class with standard Received Pronunciation. The teachers need to encourage the students to communicate in English outside the classroom.

3. The number of teachers and space need to be increased as it is often found that due to the shortage of the teachers and space, most of them have to allow a large number of students in their classes.

4. Students need to have access to suitable resources. The Libraries must contain useful books which will make students interested to go through them. Well-equipped language labs have to be set up.

5. The teachers need to go through proper training so that they are able to handle the class effectively. The teachers should think that they are not the sole authority in the class, but a facilitator who looks after the needs of the students.

Finally, it is needless to say that the most important component in a classroom is the teacher. It is in hands of the teacher to turn a monotonous class into an enjoyable one, change students' attitude positively and enhance their motivation. A teacher can utilise every resource available.

\section{Recommendations}

In order to develop speaking skills and to overcome L1 interference in the production and promotion of speaking skills, the study has some recommendations. 


\section{The students should}

- be aware of the influence of their own varieties in their spoken English. For that, they need enough drilling of Received Pronunciation of English.

- have comparative studies between sound systems of both L1 and L2, i.e. Bangla and English.

- have the knowledge of the long and short vowels of the English sound system by practising some words differentiating long and short vowels, e.g. ship or sheep, come or calm, etc.

- know the difference between diphthongs and monopthongs, and be aware of changing diphthongs to monopthongs or vice versa. So they should pronounce 'go' as /geu/, not /go:/. Some Bengali vowels can be helpful for drilling this sort of sound, e.g. /au(ঔ)/

- pronounce the consonant clusters exactly avoiding the prosthesis or epenthesis of a vowel. Continuous drilling can bring progress in this regard.

Moreover, students can enjoy English movies and dialogues and practise accordingly for the improvement of their speaking skills.

\section{Conclusion}

From the study, it is revealed that Bangladeshi learners of English, especially tertiary students, have manifold constraints when they go to produce English sound patterns. They are ignorant of the English pronunciation system, they have problems of both L1 (Bangla) interference and the influence of local varieties while they go to speak English. Moreover, they lack the proper guidelines on English pronunciation. The motivating factors from all relevant quarters can only help them to overcome the impediments to pronunciation. The move should come not only from the educational institutions and the government, but also from the guardians and the vigilant educationists. Considering the importance of English in the global context and its importance in Bangladesh for academic and professional needs- with the present infra-structure of education in our country, English is the only foreign language that can be taught more widely with correct pronunciation. Most of all, students' self-awareness can play a vital role in promoting their performance in the production of English spoken discourse avoiding all constraints and the influence of local varieties. 


\section{References:}

Amin, Sadrul. "Learning to Speak English in Bangladesh: The Current State of Affairs." Spectrum (Journal of the Department. of English, Dhaka University) 5 (2006).

Banu, Rahela. “Bangladeshi English: A New Variety?” Journal of the Institute of Modern Languages June (2000).

Hai, Muhammad Abdul, and Ball, W.J. The Sound Structures of English and Bengali. Dacca: University of Dacca, 1961.

Mujaffar, Towhid Bin. (1999). “On gees and zees: A Comparative Phonological Study Towards Better English Pronunciation." Proceedings of the International conference on National and Regional Issues in English Language Teaching: International Perspectives (ELTIP), 31 January-2 February 1999. Dhaka: British Council.

Rahman, Hamidur A.M.M. "Problems of Pronunciation for Bengali Learners of English." Journal of the Institute of Modern Languages June 1995-96.

Sultana, Rezina, and Arif, Hakim. "Self-Correction: A Possible Answer to Misspellings in English." Journal of the Institute of Modern Languages. 20 (2007). 